\title{
Construction and Content Validation of an instrument for assessment holistic Knowledge Management
}

\author{
Fabio Corrêa ${ }^{I}$ \\ https://orcid.org/0000-0002-2346-0187 \\ Fabricio ZivianïII \\ https://orcid.org/0000-0002-2705-846X \\ Dárlinton Barbosa Feres Carvalho ${ }^{I I I}$ \\ http://orcid.org/0000-0003-3844-0178 \\ Vinícius Figueiredo de Faria IV \\ https://orcid.org/0000-0002-3924-7647
}

Fernando Silva Parreiras $v$

https://orcid.org/0000-0002-9832-1501

I Universidade FUMEC, MG, Brasil.

Doutorando em andamento em Sistemas de Informação e Gestão do Conhecimento.

${ }^{I I}$ Universidade do Estado de Minas Gerais, MG, Brasil.

Professor Adjunto VI na Faculdade de Políticas Públicas.

III Universidade Federal de São João Del Rei, MG, Brasil.

Docente na UFSJ.

IV Universidade FUMEC, MG, Brasil.

Doutorando em Sistemas de Informação e Gestão do Conhecimento.

' Universidade FUMEC, MG, Brasil.

Docente na FUMEC.

http://dx.doi.org/10.1590/1981-5344/37583

Knowledge Management is a field of research that seeks to articulate the intricate relationship between the various organizational dimensions that influence in favor of knowledge. Measurement, as a dimension of this management, proposes to measure the level or capacity 
of knowledge management in organizational locus. However, the instruments for this purpose are expressed without an apparent psychometric assessment, as well as they do not articulate the holistic perspective, embodied by the totality of the critical dimensions for the success of this management. In the meantime, this research aims to build and validate an instrument for assessing holistic Knowledge Management. So, this is descriptive research with a quantitative approach, which makes use of the perception of four expert judges concerning the aspects of clarity, coherence, and pertinence of the statements of the constructed instrument. These aspects were analyzed using the Content Validation Coefficient method and must be equal to or greater than 0.70 to certify the quality of the questionnaire. The results express that the total coefficients, composed of all instrument items, are 0.87, 0.94 , and 0.95 for each aspect, respectively, attesting to the quality of that instrument. Thus, this questionnaire can be applied for purposes of organizational diagnosis, which is an opportunity for future research.

Keywords: Knowledge management; Holistic paradigm; Holistic knowledge management; Content Validation; Measurement; Diagnosis.

\section{Construção e Validação de Conteúdo de um instrumento para avaliação da Gestão do Conhecimento holística}

A Gestão do Conhecimento é um campo de pesquisa que busca articular a intricada relação entre as diversas dimensões organizacionais que se influenciam em prol do conhecimento. A mensuração, enquanto uma dimensão dessa gestão, se propõe a aferir, em determinado lócus organizacional, o nível ou a capacidade de gerenciamento do conhecimento. Contudo, os instrumentos para esse fim são expressos sem uma aparente avaliação psicométrica, bem como não articulam a perspectiva holística, 
consubstanciada pela totalidade das dimensões críticas para o sucesso dessa gestão. Neste interim, esta pesquisa objetiva construir e validar um instrumento para avaliação da Gestão do Conhecimento holística. Trata-se de uma pesquisa descritiva com abordagem quantitativa, que faz uso da percepção de quatro juízes especialistas em relação aos aspectos de clareza, coerência e pertinência das afirmativas do instrumento construído. Esses aspectos foram analisados por meio do método de Coeficiente de Validação de Conteúdo, devendo serem iguais ou superiores a 0,70 para atestar a qualidade do questionário. Os resultados expressam que os coeficientes totais, composto por todos os itens do instrumento, são de 0,87, 0,94 e 0,95 para cada aspecto, respectivamente, atestando a qualidade do referido instrumento. Assim, assume-se que este questionário pode ser aplicado para fins de diagnóstico organizacional, sendo essa uma oportunidade de pesquisa futura.

Palavras-chave: Gestão do conhecimento; Paradigma holístico; Gestão do conhecimento holística; Validação de Conteúdo; Mensuração; Diagnóstico.

Recebido em 21.12.2021 Aceito em 29.12.2021

\section{Introduction}

During the evolution of society, the productive modus operandi passed through the manual labor of the agricultural era, steam production of industrial plants in the industrial era until it reached the intellectual production, attainment of the information and knowledge era. Along this path, the preponderant organizational asset changed from a tangible form (agricultural and industrial age), such as tools, machinery, and physical installations, to an intangible form (information and knowledge age), resulting from the cognitive potential of individuals. This transformation, expressed in detail by Corrêa, Ribeiro, and Pinheiro (2017), revolutionized the economy, organizations, and society, boosting the scientific field called Knowledge Management (KM).

$\mathrm{KM}$ presents itself as a form of management that is driven to intangible assets, such as knowledge. It seeks to articulate the economic, organizational, and societal changes mentioned earlier, together with the intricate relationship between various organizational dimensions that 
influence knowledge. Zancheta and Damian (2019) highlight the culture, infrastructure, measurement, leadership, and information technology among such dimensions. In the meantime, KM models arise, also known as frameworks, to arrange the entanglement concerning these dimensions. One aspect of these structures is the diagnosis, located in the scope of the measurement dimension, being an instrument that aims to assess the level or capacity of knowledge management in a given organizational locus.

Among the various KM models that have diagnoses, such as the proposals by Bukowitz and Williams (2002), Terra (2005), and Batista (2012), two limitations stand out: 1) presentation of a psychometric assessment for instrument validation; 2) neglect of critical aspects for conducting knowledge management. The first gives quality to the instrument from the perspective of specialists in the field (HernándezNieto, 2002; Filgueiras et al., 2015), while the second expresses the articulation of all critical dimensions for the success of this administration (Santos; Damian; Valentim, 2019; Corrêa, 2020), both of which are of urgent relevance for the purposes of a diagnosis relating to this form of management.

In this sense, this research considers these limitations and addresses them with the objective of building and validating an instrument for the assessment of holistic KM. For this purpose, the following section elucidates the fundamentals of holistic KM for further explanation of the research instrument and the methodological procedures and methods for its validation. Therefore, the analysis of the results of the application of the methods is elucidated, and the conclusions are drawn.

\section{Holistic Knowledge Management}

$\mathrm{KM}$ intends to promote the management of this intangible asset in an organizational setting. As a form of management, it is related to other areas, such as human resources, strategy, and organizational culture management, among others, expressed, in summary, by Santos, Damian, and Valentim (2019). However, while some of these areas are covered by KM approaches, others are neglected, culminating in not treating all of them simultaneously. This feature is a remainder from the NewtonianCartesian scientific paradigm, also called reductionism, which points out that the "universe is a mechanical system made up of isolated parts" (Beirão et al., 2020, p. 31).

The reductionist perspective of this management can be seen in KM models, also known as structures or frameworks, which consist of schematic approaches used to express intricate relationships in a more intelligible way (Corrêa, 2020). Such models contemplate some of the areas surrounding knowledge management, isolating them from the 
others, as shown in the structures by Salzano et al. (2016) and Bem, Coelho, and Dandolini (2016). Like others, the framework by Sánchez and Ponjuán Dante (2016) contemplates culture and information technology, while the one by Farías, Mercado, and Gonzáles (2016) addresses these together with processes and activities. Therefore, the proposal by Moscoso-Zea et al. (2016) contemplates the aforementioned factors, except for culture, showing the disjoint variation of these areas in KM models.

In this sense, holistic KM establishes itself as a complement to reductionism, as it aims to treat the parts concurrently in the face of the whole (Meinicke; Santos, 2019; Miranda; Arruda; Melo, 2020). In other words, it seeks to recognize that these parts are mutually related and, therefore, must be treated together so that it is possible to contemplate the entire phenomenon. Thus, the whole is admitted in its entirety, as the connections between the parts, which also make up the totvs, are preserved and treated simultaneously. However, it is necessary to identify these parts for the constitution of the holistic perspective of $K M$, as they constitute the foundations of this management.

In summary, two guiding lines stand out: a) holistic KM is a form of management that reciprocally relates to other themes and areas of the organization to promote processes and activities based on knowledge, aiming to achieve the goals desired by the organization; b) a KM initiative is an action based on knowledge, which is put into practice in a certain organizational context. Adjusted to these outlines are the foundations of holistic KM, presented by Corrêa (2020), who consolidated the 13 areas, also called dimensions or factors, considered critical for the success of this management, which must be treated concurrently in frameworks of knowledge management, being:

1) Strategy: the organizational strategy must be aligned with the KM so that it supports the business objectives, and employees must be communicated (Corrêa, 2020). KM initiatives must be based on the company's mission, vision and values (Pereira; Skrobot; Danielsson, 2010; Batista, 2012; Probst; Raub; Romhardt, 2002);

2) Leadership and support of senior management: leadership must act as an example of behavior, and senior management must support the KM proposal and communicate it to the organization (Corrêa, 2020). Furthermore, critical knowledge gaps must be determined, aiming to remedy them to achieve what the company desires (Teixeira Filho, 2000; Batista, 2012; Fivaz; Pretorius, 2015; Salzanoet al., 2016; Bem; Coelho; Dandolini, 2016);

3) KM team: KM demands a team of professionals with specific responsibilities and activities, such as managing and coordinating, 
aiming at its longevity and achievement of the desired goals (Corrêa, 2020). Among the roles assumed by this team is the knowledge director, also called Chief Knowledge Officer (CKO) (Davenport; Prusak, 1998; Teixeira Filho, 2000; Bukowitz; Williams, 2002; Castillo; Cazarini, 2014; Bem; Coelho; Dandolini, 2016);

4) Resources (financial, human, material and time): like any organizational endeavor, KM demands financial and human resources, as well as material and time inputs for its operation (Piraquive; García; Crespo, 2015; Corrêa, 2020);

5) Processes and activities: processes and activities announce what can be done with the knowledge and determine its life cycle, with sharing, creation, and retrieval being some examples, which should be integrated into the workflow (Corrêa, 2020);

6) Human resources management: people are the pillar of $\mathrm{KM}$, given that knowledge comes from their minds. Therefore, the recruitment, development, and retention processes of employees provide the company with professionals with knowledge regarding business purposes (Corrêa, 2020), as well as the Human Resources Management's responsibility to establish career plans and guidelines for competence development (Macedo et al., 2001; Cajueiro, 2008);

7) Training and education: employees need to be educated on the specific terms and vocabulary of knowledge management and trained to handle knowledge-oriented technological systems (Corrêa, 2020). Thus, the people who will execute or manage the KM initiatives must be trained according to these specificities (Salzanoet al., 2016);

8) Motivation: financial and non-financial incentives, recognition, and valuation of the individual are needed for the collaborative involvement of employees in KM (Bukowitz; Williams, 2002; Probst; Raub; Romhardt, 2002; Terra, 2005; Batista, 2012; Castillo; Cazarini, 2014; Corrêa, 2020);

9) Teamwork: a group of individuals who interact through a common goal establish fruitful teamwork for sharing and creating knowledge (Probst; Raub; Romhardt, 2002; Corrêa, 2020). Thus, the purpose and structure of the team must be determined for the best approach to the problem or the desired improvement (Futami, 2001; Hanashiro, 2005); 
10) Culture: KM demands a culture that establishes a high degree of trust between individuals in order to promote a collaborative environment in favor of knowledge (Davenport; Prusak, 1998; Richter, 2002; Cajueiro, 2008; Pereira; Skrobot; Danielsson, 2010; Castillo; Cazarini, 2014; Salzano et al., 2016; Corrêa, 2020). Thus, the company must have tolerance for errors and understand its culture (Probst; Raub; Romhardt, 2002; Terra, 2005);

11)Information Technology: technology is a means for handling (capturing, sharing, and storing) explicit knowledge and a facilitator that connects people with views towards tacit knowledge (Corrêa, 2020). Technological solutions must be aligned with the knowledge initiative and organizational objectives, as well as being approved for implementation (Batista, 2012; Salzano et al., 2016);

12)Measurement: measurement allows identifying whether the objectives of the knowledge initiative have been achieved and measuring the progress of knowledge management (Cajueiro, 2008; Corrêa, 2020). Due to the intangibility of knowledge, the use of non-financial and/or financial metrics is acceptable, and it is required to diagnose the organizational environment with a view to knowledge and disclose the results to the organization (Bukowitz; Williams, 2002; Balceiro; Antônio, 2010; Teixeira Filho, 2000; Batista, 2012; Salzano et al., 2016);

13)Pilot Project: a knowledge initiative should be implemented on a smaller scale to capture lessons learned and best practices, aiming to increase the success of the initiative when it is implemented in greater scope (Batista, 2012; Salzano et al., 2016; Correa, 2020).

Recognizing that these factors are critical for the success of this management and, according to the precepts of the holistic paradigm, they must be dealt with together, this research uses its foundations as mentioned earlier to devise the statements (i.e., items), which comprise the instrument for the assessment of $\mathrm{KM}$ holistic. These statements are presented together with the methodological procedures.

\section{Methodological Procedures}

This research is descriptive since it aims to describe the Content Validation of the research instrument built for the assessment of holistic KM (Table 1). The sample comprises the judgments of four expert judges 
on three aspects, namely: clarity, coherence, and pertinence. The approach is, prominently, quantitative.

Table 1. Initial Holistic Knowledge Management Assessment Tool for Content Validation

\begin{tabular}{|c|c|c|}
\hline \multirow{2}{*}{$\begin{array}{l}\text { Dimension } \\
\text { (critical } \\
\text { factor) }\end{array}$} & \multicolumn{2}{|c|}{ Statement } \\
\hline & Item & Description \\
\hline \multirow{3}{*}{ Strategy } & 1 & $\begin{array}{l}\text { The organization aligns Knowledge Management initiatives with } \\
\text { organizational strategy. }\end{array}$ \\
\hline & 2 & $\begin{array}{l}\text { The organization discloses the alignment of Knowledge } \\
\text { Management initiatives with organizational strategy. }\end{array}$ \\
\hline & 3 & $\begin{array}{l}\text { Knowledge Management initiatives contemplate the organization's } \\
\text { vision, mission, and values, as well as contribute to the achievement } \\
\text { of strategic objectives. }\end{array}$ \\
\hline \multirow{3}{*}{$\begin{array}{l}\text { Leadership } \\
\text { and Support of } \\
\text { Senior } \\
\text { Management }\end{array}$} & 4 & $\begin{array}{l}\text { Senior management identifies and prioritizes Critical Knowledge } \\
\text { gaps related to Knowledge Management initiatives. }\end{array}$ \\
\hline & 5 & $\begin{array}{l}\text { Senior management grants time, as well as moral (i.e., examples } \\
\text { and words) and financial support to Knowledge Management } \\
\text { initiatives. }\end{array}$ \\
\hline & 6 & $\begin{array}{l}\text { Senior management reports the purpose of Knowledge Management } \\
\text { initiatives to the company. }\end{array}$ \\
\hline \multirow{3}{*}{ KM Team } & 7 & $\begin{array}{l}\text { The organization provides people to lead the Knowledge } \\
\text { Management initiatives. }\end{array}$ \\
\hline & 8 & $\begin{array}{l}\text { The Knowledge Management team has clearly defined profiles, } \\
\text { roles, and responsibilities. }\end{array}$ \\
\hline & 9 & $\begin{array}{l}\text { The organization has established a Knowledge Director, also called } \\
\text { Chief Knowledge Officer (CKO), and/or a Knowledge Manager. }\end{array}$ \\
\hline \multirow{3}{*}{$\begin{array}{l}\text { Resources } \\
\text { (financial, } \\
\text { human, } \\
\text { material and } \\
\text { time) }\end{array}$} & 10 & $\begin{array}{l}\text { The organization provides financial resources and physical } \\
\text { infrastructure for knowledge-oriented initiatives. }\end{array}$ \\
\hline & 11 & $\begin{array}{l}\text { The organization provides people to perform knowledge-oriented } \\
\text { initiatives. }\end{array}$ \\
\hline & 12 & $\begin{array}{l}\text { The organization makes time for people to act on knowledge- } \\
\text { oriented initiatives. }\end{array}$ \\
\hline \multirow{3}{*}{$\begin{array}{l}\text { Processes and } \\
\text { Activities }\end{array}$} & 13 & $\begin{array}{l}\text { The organization has institutionalized processes (e.g., sharing, } \\
\text { creation, retrieval) oriented to knowledge. }\end{array}$ \\
\hline & 14 & $\begin{array}{l}\text { Knowledge-oriented processes (e.g., sharing, creating, retrieving) } \\
\text { are integrated into people's workflow. }\end{array}$ \\
\hline & 15 & $\begin{array}{l}\text { Knowledge-oriented processes (e.g., sharing, creation, retrieval) are } \\
\text { proposed according to the features of the knowledge initiative(s). }\end{array}$ \\
\hline \multirow{3}{*}{$\begin{array}{l}\text { Human } \\
\text { Resources } \\
\text { Management }\end{array}$} & 16 & $\begin{array}{l}\text { The organization's knowledge gaps are considered when hiring } \\
\text { people. }\end{array}$ \\
\hline & 17 & $\begin{array}{l}\text { The organization has the means for training and further development } \\
\text { of people's skills and competencies. }\end{array}$ \\
\hline & 18 & The organization has career plans for employees. \\
\hline \multirow{3}{*}{$\begin{array}{l}\text { Training and } \\
\text { Education }\end{array}$} & 19 & $\begin{array}{l}\text { The organization promotes training(s) to standardize Knowledge } \\
\text { Management concepts and vocabulary. }\end{array}$ \\
\hline & 20 & $\begin{array}{l}\text { The organization promotes training(s) for the people who will lead } \\
\text { the Knowledge Management. }\end{array}$ \\
\hline & 21 & $\begin{array}{l}\text { The organization promotes training(s) for the people who will } \\
\text { perform the knowledge-oriented initiative(s). }\end{array}$ \\
\hline Motivation & 22 & $\begin{array}{l}\text { The organization possesses and uses methods for assessing } \\
\text { employees. }\end{array}$ \\
\hline
\end{tabular}




\begin{tabular}{|c|c|c|}
\hline \multirow{4}{*}{$\begin{array}{l}\text { Dimension } \\
\text { (critical } \\
\text { factor) }\end{array}$} & \multicolumn{2}{|c|}{ Statement } \\
\hline & Item & Description \\
\hline & 23 & $\begin{array}{l}\text { The organization implements systems for rewards (financial } \\
\text { benefits), gratuities (non-financial benefits), or employee recognition. }\end{array}$ \\
\hline & 24 & $\begin{array}{l}\text { The organization promotes ways to value collaborative behavior, } \\
\text { teamwork, and/or knowledge-oriented processes (e.g., sharing, } \\
\text { creating). }\end{array}$ \\
\hline \multirow{3}{*}{ Teamwork } & 25 & The organization fosters teamwork. \\
\hline & 26 & $\begin{array}{l}\text { The organization considers the creation of teams to support } \\
\text { knowledge-oriented initiatives. }\end{array}$ \\
\hline & 27 & $\begin{array}{l}\text { The objective and purpose of the created team(s) are presented to } \\
\text { its members. }\end{array}$ \\
\hline \multirow{3}{*}{ Culture } & 28 & $\begin{array}{l}\text { The organization is tolerant of errors and recognizes the potential for } \\
\text { learning through them, aiming to promote a collaborative } \\
\text { environment in favor of knowledge. }\end{array}$ \\
\hline & 29 & $\begin{array}{l}\text { The organization seeks to establish a culture aimed at sharing } \\
\text { knowledge. }\end{array}$ \\
\hline & 30 & $\begin{array}{l}\text { Through the knowledge-oriented initiative, the organization performs } \\
\text { a diagnosis of its organizational culture. }\end{array}$ \\
\hline \multirow{3}{*}{$\begin{array}{l}\text { Information } \\
\text { Technology }\end{array}$} & 31 & $\begin{array}{l}\text { The organization considers the appropriate technology(s) for the } \\
\text { knowledge-driven initiative. }\end{array}$ \\
\hline & 32 & $\begin{array}{l}\text { The organization has technological means (e.g., e-mail, chats) to } \\
\text { establish a connection between people. }\end{array}$ \\
\hline & 33 & $\begin{array}{l}\text { The organization seeks the consent of senior management } \\
\text { regarding the technology(s) to be acquired or customized to meet } \\
\text { the knowledge-oriented initiative. }\end{array}$ \\
\hline \multirow{3}{*}{ Measurement } & 34 & $\begin{array}{l}\text { The organization has financial and/or non-financial indicators and } \\
\text { metrics for measuring knowledge-oriented initiatives. }\end{array}$ \\
\hline & 35 & $\begin{array}{l}\text { The organization performs Knowledge Management diagnoses, } \\
\text { aiming to identify gaps to be covered. }\end{array}$ \\
\hline & 36 & $\begin{array}{l}\text { The organization discloses the results of Knowledge Management } \\
\text { initiatives and diagnoses to employees. }\end{array}$ \\
\hline \multirow{3}{*}{ Pilot Project } & 37 & $\begin{array}{l}\text { The organization first implements the knowledge initiative(s) on a } \\
\text { smaller scale for later implementation on a larger organizational } \\
\text { scale. }\end{array}$ \\
\hline & 38 & $\begin{array}{l}\text { The organization evaluates the results obtained by implementing the } \\
\text { knowledge initiative on a smaller scale (i.e., pilot) for further } \\
\text { implementation on a broader organizational scale. }\end{array}$ \\
\hline & 39 & $\begin{array}{l}\text { The lessons learned through the knowledge-oriented initiative(s) are } \\
\text { recorded. }\end{array}$ \\
\hline
\end{tabular}

Source: Research data, Belo Horizonte (2020).

Below the original text in Portuguese according to the research result.

Table 1. Initial Holistic Knowledge Management Assessment Tool for Content Validation

\begin{tabular}{l|c|l}
\hline $\begin{array}{l}\text { Dimension } \\
\text { (critical } \\
\text { factor) }\end{array}$ & \multicolumn{2}{|l}{ Statement } \\
\cline { 2 - 3 } & Item & Description \\
\hline \multirow{3}{*}{ Strategy } & 1 & $\begin{array}{l}\text { A organização realiza o alinhamento das iniciativas de Gestão do } \\
\text { Conhecimento à estratégia organizacional. }\end{array}$ \\
\cline { 2 - 3 } & 2 & $\begin{array}{l}\text { A organização divulga o alinhamento das iniciativas de Gestão do } \\
\text { Conhecimento à estratégia organizacional. }\end{array}$ \\
\hline
\end{tabular}




\begin{tabular}{|c|c|c|}
\hline \multirow{3}{*}{$\begin{array}{l}\text { Dimension } \\
\text { (critical } \\
\text { factor) }\end{array}$} & \multicolumn{2}{|c|}{ Statement } \\
\hline & Item & Description \\
\hline & 3 & $\begin{array}{l}\text { As iniciativas da Gestão do Conhecimento contemplam a visão, } \\
\text { missão e valores da organiz ação, bem como contribuem para o } \\
\text { atingimento dos objetivos estratégicos. }\end{array}$ \\
\hline \multirow{3}{*}{$\begin{array}{l}\text { Leadership } \\
\text { and support of } \\
\text { senior } \\
\text { management }\end{array}$} & 4 & $\begin{array}{l}\text { A alta administração identifica e prioriza lacunas de Conhecimentos } \\
\text { Críticos relacionadas as iniciativas de Gestão do Conhecimento. }\end{array}$ \\
\hline & 5 & $\begin{array}{l}\text { A alta administração concede tempo, bem como apoia moralmente } \\
\text { (exemplos e palavras) e financeiramente às iniciativas de Gestão do } \\
\text { Conhecimento. }\end{array}$ \\
\hline & 6 & $\begin{array}{l}\text { A alta administração comunica à empresa o propósito das iniciativas } \\
\text { de Gestão do Conhecimento. }\end{array}$ \\
\hline \multirow{3}{*}{ KM team } & 7 & $\begin{array}{l}\text { A organização disponibiliza pessoas para conduzir (gerir) as } \\
\text { iniciativas de Gestão do Conhecimento. }\end{array}$ \\
\hline & 8 & $\begin{array}{l}\text { A equipe de Gestão do Conhecimento possui perfis, papeis e } \\
\text { responsabilidades claramente definidos. }\end{array}$ \\
\hline & 9 & $\begin{array}{l}\text { A organização instituiu um Diretor de Conhecimento, também } \\
\text { denominado ChiefKnowledge Officer (CKO), e, ou, um Gerente de } \\
\text { Conhecimento. }\end{array}$ \\
\hline \multirow{3}{*}{$\begin{array}{l}\text { Resources } \\
\text { (financial, } \\
\text { human, } \\
\text { material and } \\
\text { time) }\end{array}$} & 10 & $\begin{array}{l}\text { A organização disponibiliza recursos financeiros e infraestrutura } \\
\text { física para as iniciativas orientadas ao conhecimento. }\end{array}$ \\
\hline & 11 & $\begin{array}{l}\text { A organização disponibiliza pessoas para realizar (executar) as } \\
\text { iniciativas orientadas ao conhecimento. }\end{array}$ \\
\hline & 12 & $\begin{array}{l}\text { A organização disponibiliza tempo para que as pessoas atuem nas } \\
\text { iniciativas orientadas ao conhecimento. }\end{array}$ \\
\hline \multirow{3}{*}{$\begin{array}{l}\text { Processes } \\
\text { andactivities }\end{array}$} & 13 & $\begin{array}{l}\text { A organização possui processos institucionalizados } \\
\text { (compartilhamento, criação, recuperação, outros) orientados ao } \\
\text { conhecimento. }\end{array}$ \\
\hline & 14 & $\begin{array}{l}\text { Os processos orientados ao conhecimento (compartilhamento, } \\
\text { criação, recuperação, outros) estão integrados ao fluxo de trabalho } \\
\text { das pessoas. }\end{array}$ \\
\hline & 15 & $\begin{array}{l}\text { Os processos orientados ao conhecimento (compartilhamento, } \\
\text { criação, recuperação, outros) são propostos segundo as } \\
\text { particularidades da(s) iniciativa(s) de conhecimento. }\end{array}$ \\
\hline \multirow{3}{*}{$\begin{array}{l}\text { Humanresourc } \\
\text { es } \\
\text { management }\end{array}$} & 16 & $\begin{array}{l}\text { As lacunas de conhecimento da organização são consideradas na } \\
\text { contratação de pessoas. }\end{array}$ \\
\hline & 17 & $\begin{array}{l}\text { A organização dispõe de meios para a capacitação } \\
\text { (desenvolvmento) das habilidades e competências das pessoas. }\end{array}$ \\
\hline & 18 & A organização dispõe de planos de carreiras para os funcionários. \\
\hline \multirow{3}{*}{$\begin{array}{l}\text { Training } \\
\text { andeducation }\end{array}$} & 19 & $\begin{array}{l}\text { A organização promove treinamento(s) para homogeneizar } \\
\text { conceitos e vocabulário da Gestão do Conhecimento. }\end{array}$ \\
\hline & 20 & $\begin{array}{l}\text { A organização promove treinamento(s) para as pessoas que } \\
\text { conduzirão (gestão) a Gestão do Conhecimento. }\end{array}$ \\
\hline & 21 & $\begin{array}{l}\text { A organização promove treinamento(s) para as pessoas que } \\
\text { realizarão (executarão) a(s) iniciativa(s) orientada(s) ao } \\
\text { conhecimento. }\end{array}$ \\
\hline \multirow{3}{*}{ Motivation } & 22 & $\begin{array}{l}\text { A organização dispõe e faz uso de métodos para avaliação dos } \\
\text { funcionários. }\end{array}$ \\
\hline & 23 & $\begin{array}{l}\text { A organização implementa sistemas de recompensas (financeiras), } \\
\text { gratificações (benefícios não financeiros) ou reconhecimento dos } \\
\text { funcionários. }\end{array}$ \\
\hline & 24 & $\begin{array}{l}\text { A organização promove meios para valorizar o comportamento } \\
\text { colaborativo, o trabalho em equipe e, ou, os processos orientados } \\
\text { ao conhecimento (compartilhamento, criação, outros). }\end{array}$ \\
\hline \multirow{2}{*}{ Teamwork } & 25 & A organização incentiva o trabalho em equipe. \\
\hline & 26 & A organização considera a criação de equipes para atendimento das \\
\hline
\end{tabular}




\begin{tabular}{|c|c|c|}
\hline \multirow{4}{*}{$\begin{array}{l}\text { Dimension } \\
\text { (critical } \\
\text { factor) }\end{array}$} & \multicolumn{2}{|c|}{ Statement } \\
\hline & Item & Description \\
\hline & & iniciativas orientadas ao conhecimento. \\
\hline & 27 & $\begin{array}{l}\text { O objetivo e propósito da(s) equipe(s) criada(s) é apresentado aos } \\
\text { seus integrantes. }\end{array}$ \\
\hline \multirow{3}{*}{ Culture } & 28 & $\begin{array}{l}\text { A organização é tolerante a erros e reconhece o potencial de } \\
\text { aprendizado por meio desses, visando a promoção de um ambiente } \\
\text { colaborativo em prol do conhecimento. }\end{array}$ \\
\hline & 29 & $\begin{array}{l}\text { A organização busca estabelecer uma cultura que visa o } \\
\text { compartilhamento de conhecimento. }\end{array}$ \\
\hline & 30 & $\begin{array}{l}\text { Mediante a iniciativa orientada ao conhecimento a organiz ação } \\
\text { realiza um diagnóstico de sua cultura organizacional. }\end{array}$ \\
\hline \multirow{3}{*}{$\begin{array}{l}\text { Informationtec } \\
\text { hnology }\end{array}$} & 31 & $\begin{array}{l}\text { A organização pondera sobre a(s) tecnologia(s) adequada(s) à } \\
\text { iniciativa orientada ao conhecimento. }\end{array}$ \\
\hline & 32 & $\begin{array}{l}\text { A organização dispõe de meios tecnológicos (e-mail, chats, outros) } \\
\text { para estabelecer a conexão entre as pessoas. }\end{array}$ \\
\hline & 33 & $\begin{array}{l}\text { A organização busca consentimento da alta administração quanto } \\
\text { a(s) tecnologia(s) a serem adquiridas ou customizadas para } \\
\text { atendimento da iniciativa orientada ao conhecimento. }\end{array}$ \\
\hline \multirow{3}{*}{ Measurement } & 34 & $\begin{array}{l}\text { A organização possui indicadores e métricas, financeiros e, ou, não } \\
\text { financeiros, para medição das iniciativas orientadas ao } \\
\text { conhecimento. }\end{array}$ \\
\hline & 35 & $\begin{array}{l}\text { A organização realiza diagnósticos da Gestão do Conhecimento, } \\
\text { visando identificar lacunas a serem sanadas. }\end{array}$ \\
\hline & 36 & $\begin{array}{l}\text { A organização divulga aos funcionários os resultados das iniciativas } \\
\text { e diagnósticos de Gestão do Conhecimento. }\end{array}$ \\
\hline \multirow{3}{*}{ Pilot Project } & 37 & $\begin{array}{l}\text { A organização realiza, primeiramente, a implantação da(s) } \\
\text { iniciativa(s) de conhecimento em menor escala para posterior } \\
\text { implantação em maior amplitude organizacional. }\end{array}$ \\
\hline & 38 & $\begin{array}{l}\text { A organização avalia os resultados obtidos pela implantação da } \\
\text { iniciativa de conhecimento em menor escala organizacional. }\end{array}$ \\
\hline & 39 & $\begin{array}{l}\text { As lições aprendidas, obtidas por meio da(s) iniciativa(s) orientadas } \\
\text { ao conhecimento, são registradas. }\end{array}$ \\
\hline
\end{tabular}

Source: Research data, Belo Horizonte (2020).

The 39 statements expressed in Table 1 were built upon the theoretical foundations expressed in this research (section 2). Thus, these foundations, the aforementioned statements, as well as the guiding lines holistic KM and KM initiative - were submitted to four judges specialized in KM to carry out the Content Validation, as follows: judge 1) Ph.D. in KM; judge 2) Ph.D. in KM; judges 3) Ph.D. in $K M$; judge 4) Ph.D. in Information Science. The selection criterion for the judges regarded the selection in the area of their doctoral training, all related to $\mathrm{KM}$, and the minimum of four publications on this topic in 2019-2020.

The judges' evaluation was carried out considering three aspects: 1) clarity: understanding of the statement; 2) coherence: the statement reflects the dimension in which it is attached, and 3) pertinence: the statement follows its theoretical foundations. For each statement, the three aspects were evaluated on a 5-point Likert scale, ranging from 1Much lower to 5-Much higher, of mandatory nature. The judges were invited to participate, and, upon acceptance, the guiding plans were sent 
along with the statements and their foundations, expressed in section 2 of this paper, through a Microsoft Excel ${ }^{\circ}$ file so that they could read and analyze the questions offline. Furthermore, experts could suggest changes in the writing of the statements. The evaluation was carried out in two stages, the first between $11 / 23 / 2020$ and $12 / 07 / 2020$ and the second between $12 / 8 / 2020$ and $12 / 10 / 2020$.

The data analysis employed the Content Validity Coefficient (CVC), which was suggested by Hernández-Nieto (2002) to quantify and interpret the judging of items and scales by a group of specialists in a given construct, and is commonly applied in research of such intent, as in Filgueiras et al. (2015) and Silveira et al. (2018). Quality is expressed by the CVC score of the judged item $\left(\mathrm{CVC}_{\mathrm{c}}\right)$ and by the total CVC score $\left(C V C_{t}\right)$, the second consisting of all items, both of which must be greater than or equal to 0.70 (SILVEIRA et al., 2018). For a CVC lower than accepted as a quality criterion, Hernandez-Nieto (2002) proposes an adjustment of the item and forwarding it for a new evaluation by the judges, which explains the second stage with the judges. The CVC is computed through five steps (HERNÁNDEZ-NIETO, 2002).
(1)
(2)
(3)
$M_{x}=\frac{\sum_{i=1}^{J} x_{i}}{J} \quad C V C_{i}=\frac{M_{x}}{V \max } \quad P e_{i}\left(\frac{1}{y}\right)^{I}$
(4)
(5)
$C V C_{e}=C V C_{\mathrm{i}}-P e_{\mathrm{i}} \quad C V C_{\mathrm{t}}=M C V C_{\mathrm{i}}-M P e_{\mathrm{i}}$

Through the judges' scores, the sum of each aspect per item (statement) is performed, and this quantity is divided by the number of judges to obtain the average $\left(M_{x}\right)$. In sequence, the initial CVC $\left(C V C_{i}\right)$ of each statement is calculated, dividing the calculated mean value by the maximum point of the Likert scale applied, in this case 5 . The third step is to calculate the Standard Error $\left(P e_{i}\right)$, which is obtained by the ratio of 1 over the number of judges $(J)$ to the number of judges $(J)$. Therefore, the composite CVC $\left(\mathrm{CVC}_{c}\right)$ of each aspect - clarity, coherence, and theoretical pertinence - is calculated by subtracting the Standard Error value from the initial CVC. Finally, the calculation of the total CVC $\left(C V C_{t}\right)$ is computed by subtracting the mean value of the Standard Error from the mean of the composite CVC. These calculations were performed using Microsoft Excel®.

\section{Analysis and Results}

The quality of the research instrument is expressed by the CVC score of the item judged and the total CVC score, which must be equal to or greater than 0.70 (Silveira et al. 2018). The calculation (Step 1) for each item is presented in Table 2.

Table2.Step 1: Content Validation Coefficient for each item of the holistic knowledge management assessment instrument. 


\begin{tabular}{|c|c|c|c|c|c|c|c|c|c|}
\hline \multirow{2}{*}{ Item } & \multicolumn{3}{|c|}{ Clarity } & \multicolumn{3}{|c|}{ Coherence } & \multicolumn{3}{|c|}{ Pertinence } \\
\hline & $M_{x}$ & $\mathrm{CVC}_{\mathrm{i}}$ & $\mathrm{CVC}_{\mathrm{c}}$ & $\mathbf{M}_{\mathbf{x}}$ & $\mathrm{CVC}_{\mathrm{i}}$ & $\mathrm{CVC}_{\mathrm{c}}$ & $\mathbf{M}_{\mathbf{x}}$ & $\mathrm{CVC}_{\mathrm{i}}$ & $\mathrm{CVC}_{\mathrm{c}}$ \\
\hline 1 & 5.00 & 1.00 & 1.00 & 5.00 & 1.00 & 1.00 & 5.00 & 1.00 & 1.00 \\
\hline 2 & 4.50 & 0.90 & 0.90 & 5.00 & 1.00 & 1.00 & 4.75 & 0.95 & 0.95 \\
\hline 3 & 5.00 & 1.00 & 1.00 & 5.00 & 1.00 & 1.00 & 4.75 & 0.95 & 0.95 \\
\hline 4 & 3.25 & 0.65 & 0.65 & 4.50 & 0.90 & 0.90 & 4.75 & 0.95 & 0.95 \\
\hline 5 & 5.00 & $\overline{1.00}$ & $\overline{1.00}$ & 5.00 & 1.00 & 1.00 & 5.00 & 1.00 & 1.00 \\
\hline 6 & 4.75 & 0.95 & 0.95 & 4.75 & 0.95 & 0.95 & 4.75 & 0.95 & 0.95 \\
\hline 7 & 5.00 & 1.00 & 1.00 & 5.00 & 1.00 & 1.00 & 5.00 & 1.00 & 1.00 \\
\hline 8 & 4.75 & 0.95 & 0.95 & 5.00 & 1.00 & 1.00 & 5.00 & 1.00 & 1.00 \\
\hline 9 & 4.75 & 0.95 & 0.95 & 4.75 & 0.95 & 0.95 & 4.50 & 0.90 & 0.90 \\
\hline 10 & 4.25 & 0.85 & 0.85 & 5.00 & 1.00 & 1.00 & 5.00 & 1.00 & 1.00 \\
\hline 11 & 4.50 & 0.90 & 0.90 & 5.00 & 1.00 & 1.00 & 5.00 & 1.00 & 1.00 \\
\hline 12 & 4.50 & 0.90 & 0.90 & 5.00 & 1.00 & 1.00 & 5.00 & 1.00 & 1.00 \\
\hline 13 & 4.00 & 0.80 & 0.80 & 4.75 & 0.95 & 0.95 & 5.00 & 1.00 & 1.00 \\
\hline 14 & 4.25 & 0.85 & 0.85 & 5.00 & 1.00 & 1.00 & 5.00 & 1.00 & 1.00 \\
\hline 15 & 3.50 & 0.70 & 0.70 & 4.25 & 0.85 & 0.85 & 4.75 & 0.95 & 0.95 \\
\hline 16 & 4.25 & 0.85 & 0.85 & 4.25 & 0.85 & 0.85 & 4.75 & 0.95 & 0.95 \\
\hline 17 & 5.00 & 1.00 & 1.00 & 4.50 & 0.90 & 0.90 & 4.50 & 0.90 & 0.90 \\
\hline 18 & 4.50 & 0.90 & 0.90 & 4.00 & 0.80 & 0.80 & 4.00 & 0.80 & 0.80 \\
\hline 19 & 4.50 & 0.90 & 0.90 & 5.00 & 1.00 & 1.00 & 5.00 & 1.00 & 1.00 \\
\hline 20 & 4.25 & 0.85 & 0.85 & 4.50 & 0.90 & 0.90 & 5.00 & 1.00 & 1.00 \\
\hline 21 & 4.50 & 0.90 & 0.90 & 5.00 & 1.00 & 1.00 & 5.00 & 1.00 & 1.00 \\
\hline 22 & 4.50 & 0.90 & 0.90 & 4.00 & 0.80 & 0.80 & 4.00 & 0.80 & 0.80 \\
\hline 23 & 5.00 & 1.00 & 1.00 & 5.00 & 1.00 & 1.00 & 5.00 & 1.00 & 1.00 \\
\hline 24 & 4.50 & 0.90 & 0.90 & 5.00 & 1.00 & 1.00 & 5.00 & 1.00 & 1.00 \\
\hline 25 & 4.50 & 0.90 & 0.90 & 4.50 & 0.90 & 0.90 & 4.50 & 0.90 & 0.90 \\
\hline 26 & 3.75 & 0.75 & 0.75 & 4.25 & 0.85 & 0.85 & 4.50 & 0.90 & 0.90 \\
\hline 27 & 3.50 & 0.70 & 0.70 & 4.50 & 0.90 & 0.90 & 4.50 & 0.90 & 0.90 \\
\hline 28 & 3.75 & 0.75 & 0.75 & 3.25 & 0.65 & 0.65 & 3.75 & 0.75 & 0.75 \\
\hline 29 & 4.50 & 0.90 & 0.90 & 5.00 & 1.00 & 1.00 & 5.00 & 1.00 & 1.00 \\
\hline 30 & 3.75 & 0.75 & 0.75 & 3.75 & 0.75 & 0.75 & 3.75 & 0.75 & 0.75 \\
\hline 31 & 3.50 & 0.70 & 0.70 & 4.50 & 0.90 & 0.90 & 4.50 & 0.90 & 0.90 \\
\hline 32 & 3.75 & 0.75 & 0.75 & 4.75 & 0.95 & 0.95 & 4.75 & 0.95 & 0.95 \\
\hline 33 & 3.50 & 0.70 & 0.70 & 4.75 & 0.95 & 0.95 & 4.75 & 0.95 & 0.95 \\
\hline 34 & 4.50 & 0.90 & 0.90 & 5.00 & 1.00 & 1.00 & 5.00 & 1.00 & 1.00 \\
\hline 35 & 4.75 & 0.95 & 0.95 & 4.75 & 0.95 & 0.95 & 5.00 & 1.00 & 1.00 \\
\hline 36 & 4.75 & 0.95 & 0.95 & 4.75 & 0.95 & 0.95 & 4.50 & 0.90 & 0.90 \\
\hline 37 & 4.50 & 0.90 & 0.90 & 5.00 & 1.00 & 1.00 & 5.00 & 1.00 & 1.00 \\
\hline 38 & 3.25 & 0.65 & 0.65 & 4.00 & 0.80 & 0.80 & 4.00 & 0.80 & 0.80 \\
\hline 39 & 3.50 & $\overline{0.70}$ & $\overline{0.70}$ & 4.00 & 0.80 & 0.80 & 4.00 & 0.80 & 0.80 \\
\hline$\overline{c V C_{t}}$ & - & - & 0.86 & - & - & 0.93 & - & - & 0.94 \\
\hline
\end{tabular}

Caption: $\mathrm{M}_{\mathrm{x}}$ : average of the grades of each item; $\mathrm{CVC}_{\mathrm{i}}$ : Initial Content Validity Calculation; $\mathrm{CVC}_{\mathrm{c}}$ : Composite Content Validity Calculation.

Source: Research data, Belo Horizonte (2020).

For the item whose $\mathrm{CVC}_{\mathrm{c}}$ (composite) is less than the accepted as the quality criterion $\left(\mathrm{CVC}_{c}<0.70\right)$, Hernandez-Nieto (2002) proposes its adjustment followed by a new evaluation. Item 4 presented $\mathrm{CVC}_{\mathrm{c}}$ of the clarity aspect of less than 0.70, as well as the following concerns: judge 3 ) "It is not clear the relationship between KM and critical knowledge in the matter - for example, what is considered critical knowledge"; judge 4) 
"perhaps put an example of critical knowledge". In consideration of the suggestions, the afore mentioned statement was modified from "A alta administração identifica e prioriza lacunas de Conhecimentos Críticos relacionadas as iniciativas de Gestão do Conhecimento" to "A alta administração identifica e prioriza gaps de conhecimentos indispensáveis (exemplo: ausência de conhecimento necessário para determinada atividade) a operacionalização das iniciativas de Gestão do Conhecimento".

In the me an time, item 28, under the statement "A organização é tolerante a erros e reconhece o potencial de aprendizado por meio desses, visando a promoção de um ambiente colaborativo em prol do conhecimento", did not reach a quality coefficient equal to or greater than 0.70 in the consistency aspect (Table 2). Judge 3 pondered: "Sentence is confused; there are two assertions in the same sentence". Thus, the afore mentioned item was changed to "A organização é tolerante a erros e reconhece o potencial de aprendizado por meio desses".

Likewise, item 38 presented a coefficient, referring to the clarity aspect, of 0.65 . Judge 1 pointed out the need to "Refer to the pilot project", while Judge 4 considered that "it could complement: to be used in a larger project". Thus, the statement was changed from "A organização avalia os resultados obtidos pela implantação da iniciativa de conhecimento em menor escala organizacional" to "A organização avalia os resultados obtidos pela implantação da iniciativa de conhecimento em menor escala organizacional (piloto) para posterior implantação em maior amplitude".

Through the aforementioned changes in items 4, 28, and 38, the corresponding statements were sent back to the experts for a new assessment (Step 2) during the period from 12/08/2020 to 12/09/2020, as suggested by Hernandez-Nieto (2002). Considering that the $\mathrm{CVC}_{\mathrm{c}}$ is computed based on the values of all items, its recalculation was performed and is expressed in Table 3.

Table3. Step 2: Content Validation Coefficient for each item of the holistic knowledge management assessment instrument.

\begin{tabular}{c|c|c|c|c|c|c|c|c|c}
\hline \multirow{2}{*}{ Item } & \multicolumn{3}{|c|}{ Clarity } & \multicolumn{3}{|c|}{ Coherence } & \multicolumn{3}{c}{ Pertinence } \\
\cline { 2 - 10 } & $\mathbf{M}_{\mathbf{x}}$ & $\mathbf{C V C}_{\mathbf{i}}$ & $\mathbf{C V C}_{\mathbf{c}}$ & $\mathbf{M}_{\mathbf{x}}$ & $\mathbf{C V C}_{\mathbf{i}}$ & $\mathbf{C V C}_{\mathbf{c}}$ & $\mathbf{M}_{\mathbf{x}}$ & $\mathbf{C V C}_{\mathbf{i}}$ & $\mathbf{C V C}_{\mathbf{c}}$ \\
\hline 1 & 5.00 & 1.00 & 1.00 & 5.00 & 1.00 & 1.00 & 5.00 & 1.00 & 1.00 \\
\hline 2 & 4.50 & 0.90 & 0.90 & 5.00 & 1.00 & 1.00 & 4.75 & 0.95 & 0.95 \\
\hline 3 & 5.00 & 1.00 & 1.00 & 5.00 & 1.00 & 1.00 & 4.75 & 0.95 & 0.95 \\
\hline 4 & 5.00 & 1.00 & 1.00 & 4.50 & 0.90 & 0.90 & 4.75 & 0.95 & 0.95 \\
\hline 5 & 5.00 & 1.00 & 1.00 & 5.00 & 1.00 & 1.00 & 5.00 & 1.00 & 1.00 \\
\hline 6 & 4.75 & 0.95 & 0.95 & 4.75 & 0.95 & 0.95 & 4.75 & 0.95 & 0.95 \\
\hline 7 & 5.00 & 1.00 & 1.00 & 5.00 & 1.00 & 1.00 & 5.00 & 1.00 & 1.00 \\
\hline 8 & 4.75 & 0.95 & 0.95 & 5.00 & 1.00 & 1.00 & 5.00 & 1.00 & 1.00 \\
\hline 9 & 4.75 & 0.95 & 0.95 & 4.75 & 0.95 & 0.95 & 4.50 & 0.90 & 0.90 \\
\hline
\end{tabular}




\begin{tabular}{|c|c|c|c|c|c|c|c|c|c|}
\hline \multirow{2}{*}{ Item } & \multicolumn{3}{|c|}{ Clarity } & \multicolumn{3}{|c|}{ Coherence } & \multicolumn{3}{|c|}{ Pertinence } \\
\hline & $\mathbf{M}_{\mathbf{x}}$ & $\mathrm{CVC}_{\mathrm{i}}$ & $\mathrm{CVC}_{\mathrm{c}}$ & $\mathbf{M}_{\mathbf{x}}$ & $\overline{C V C}_{\mathrm{i}}$ & $\mathbf{C V C}_{\mathrm{c}}$ & $M_{x}$ & $\overline{C V C}_{\mathbf{i}}$ & $\mathrm{CVC}_{\mathrm{c}}$ \\
\hline 10 & 4.25 & 0.85 & 0.85 & 5.00 & 1.00 & 1.00 & 5.00 & 1.00 & 1.00 \\
\hline 11 & 4.50 & 0.90 & 0.90 & 5.00 & 1.00 & 1.00 & 5.00 & 1.00 & 1.00 \\
\hline 12 & 4.50 & 0.90 & 0.90 & 5.00 & 1.00 & 1.00 & 5.00 & 1.00 & 1.00 \\
\hline 13 & 4.00 & 0.80 & 0.80 & 4.75 & 0.95 & 0.95 & 5.00 & 1.00 & 1.00 \\
\hline 14 & 4.25 & 0.85 & 0.85 & 5.00 & 1.00 & 1.00 & 5.00 & 1.00 & 1.00 \\
\hline 15 & 3.50 & 0.70 & 0.70 & 4.25 & 0.85 & 0.85 & 4.75 & 0.95 & 0.95 \\
\hline 16 & 4.25 & 0.85 & 0.85 & 4.25 & 0.85 & 0.85 & 4.75 & 0.95 & 0.95 \\
\hline 17 & 5.00 & 1.00 & 1.00 & 4.50 & 0.90 & 0.90 & 4.50 & 0.90 & 0.90 \\
\hline 18 & 4.50 & 0.90 & 0.90 & 4.00 & 0.80 & 0.80 & 4.00 & 0.80 & 0.80 \\
\hline 19 & 4.50 & 0.90 & 0.90 & 5.00 & 1.00 & 1.00 & 5.00 & 1.00 & 1.00 \\
\hline 20 & 4.25 & 0.85 & 0.85 & 4.50 & 0.90 & 0.90 & 5.00 & 1.00 & 1.00 \\
\hline 21 & 4.50 & 0.90 & 0.90 & 5.00 & 1.00 & 1.00 & 5.00 & 1.00 & 1.00 \\
\hline 22 & 4.50 & 0.90 & 0.90 & 4.00 & 0.80 & 0.80 & 4.00 & 0.80 & 0.80 \\
\hline 23 & 5.00 & 1.00 & 1.00 & 5.00 & 1.00 & 1.00 & 5.00 & 1.00 & 1.00 \\
\hline 24 & 4.50 & 0.90 & 0.90 & 5.00 & 1.00 & 1.00 & 5.00 & 1.00 & 1.00 \\
\hline 25 & 4.50 & 0.90 & 0.90 & 4.50 & 0.90 & 0.90 & 4.50 & 0.90 & 0.90 \\
\hline 26 & 3.75 & 0.75 & 0.75 & 4.25 & 0.85 & 0.85 & 4.50 & 0.90 & 0.90 \\
\hline 27 & 3.50 & 0.70 & 0.70 & 4.50 & 0.90 & 0.90 & 4.50 & 0.90 & 0.90 \\
\hline 28 & 4.00 & 0.80 & 0.80 & 4.75 & 0.95 & 0.95 & 4.75 & 0.95 & 0.95 \\
\hline 29 & 4.50 & 0.90 & 0.90 & 5.00 & 1.00 & 1.00 & 5.00 & 1.00 & 1.00 \\
\hline 30 & 3.75 & 0.75 & 0.75 & 3.75 & 0.75 & 0.75 & 3.75 & 0.75 & 0.75 \\
\hline 31 & 3.50 & 0.70 & 0.70 & 4.50 & 0.90 & 0.90 & 4.50 & 0.90 & 0.90 \\
\hline 32 & 3.75 & 0.75 & 0.75 & 4.75 & 0.95 & 0.95 & 4.75 & 0.95 & 0.95 \\
\hline 33 & 3.50 & 0.70 & 0.70 & 4.75 & 0.95 & 0.95 & 4.75 & 0.95 & 0.95 \\
\hline 34 & 4.50 & 0.90 & 0.90 & 5.00 & 1.00 & 1.00 & 5.00 & 1.00 & 1.00 \\
\hline 35 & 4.75 & 0.95 & 0.95 & 4.75 & 0.95 & 0.95 & 5.00 & 1.00 & 1.00 \\
\hline 36 & 4.75 & 0.95 & 0.95 & 4.75 & 0.95 & 0.95 & 4.50 & 0.90 & 0.90 \\
\hline 37 & 4.50 & 0.90 & 0.90 & 5.00 & 1.00 & 1.00 & 5.00 & 1.00 & 1.00 \\
\hline 38 & 4.00 & 0.80 & 0.80 & 4.75 & 0.95 & 0.95 & 5.00 & 1.00 & 1.00 \\
\hline 39 & 3.50 & 0.70 & 0.70 & 4.00 & 0.80 & 0.80 & 4.00 & 0.80 & 0.80 \\
\hline$\overline{C V C_{t}}$ & - & - & 0.87 & - & - & 0.94 & - & - & 0.95 \\
\hline
\end{tabular}

Caption: $\mathrm{M}_{\mathrm{x}}$ : average of the grades of each item; $\mathrm{CVC}_{\mathrm{i}}$ : Initial Content Validity Calculation; $\mathrm{CVC}_{\mathrm{c}}$ : Composite Content Validity Calculation.

Source: Research data, Belo Horizonte (2020).

Thus, items 4,28 , and 38, reassessed by judges, reached $\mathrm{CVC}_{\mathrm{c}}$ of $1.00,0.90$, and 0.95, respectively, as well as all others, reached these coefficients with values equal to or greater than 0.70. Furthermore, the total CVC $\left(\mathrm{CVC}_{\mathrm{t}}\right)$, composed of all items, presented values of $0.87,0.94$, and 0.95, respectively, for the aspects of clarity, coherence, and pertinence, being higher than the established 0.70 . It means that the 39 statements present, through the experts' perception, clarity of understanding, consistency regarding the statement matching the dimension in which it is included, as well as are pertinent regarding its theoretical foundations. Table 4 expresses the final version of this research instrument. 
Table4. The final version of the assessment tool for holistic knowledge management

\begin{tabular}{|c|c|c|}
\hline \multirow{2}{*}{$\begin{array}{l}\text { Dimension } \\
\text { (critical } \\
\text { factor) }\end{array}$} & \multicolumn{2}{|c|}{ Statement } \\
\hline & Item & Description \\
\hline \multirow{3}{*}{ Strategy } & 1 & $\begin{array}{l}\text { A organização realiza o alinhamento das iniciativas de Gestão do } \\
\text { Conhecimento à estratégia organizacional. }\end{array}$ \\
\hline & 2 & $\begin{array}{l}\text { A organização divulga o alinhamento das iniciativas de Gestão do } \\
\text { Conhecimento à estratégia organizacional. }\end{array}$ \\
\hline & 3 & $\begin{array}{l}\text { As iniciativas da Gestão do Conhecimento contemplam a visão, } \\
\text { missão e valores da organiz ação, bem como contribuem para o } \\
\text { atingimento dos objetivos estratégicos. }\end{array}$ \\
\hline \multirow{3}{*}{$\begin{array}{l}\text { Leadership } \\
\text { and support of } \\
\text { senior } \\
\text { management }\end{array}$} & 4 & $\begin{array}{l}\text { A alta administração identifica e prioriza gaps de conhecimentos } \\
\text { indispensáveis (exemplo: ausência de conhecimento necessário } \\
\text { para determinada atividade) a operacionalização das iniciativas de } \\
\text { Gestão do Conhecimento. }\end{array}$ \\
\hline & 5 & $\begin{array}{l}\text { A alta administração concede tempo, bem como apoia moralmente } \\
\text { (exemplos e palavras) e financeiramente às iniciativas de Gestão do } \\
\text { Conhecimento. }\end{array}$ \\
\hline & 6 & $\begin{array}{l}\text { A alta administração comunica à empresa o propósito das iniciativas } \\
\text { de Gestão do Conhecimento. }\end{array}$ \\
\hline \multirow{3}{*}{ KM team } & 7 & $\begin{array}{l}\text { A organização disponibiliza pessoas para conduzir (gerir) as } \\
\text { iniciativas de Gestão do Conhecimento. }\end{array}$ \\
\hline & 8 & $\begin{array}{l}\text { A equipe de Gestão do Conhecimento possui perfis, papeis e } \\
\text { responsabilidades claramente definidos. }\end{array}$ \\
\hline & 9 & $\begin{array}{l}\text { A organização instituiu um Diretor de Conhecimento, também } \\
\text { denominado ChiefKnowledge Officer (CKO), e, ou, um Gerente de } \\
\text { Conhecimento. }\end{array}$ \\
\hline \multirow{3}{*}{$\begin{array}{l}\text { Resources } \\
\text { (financial, } \\
\text { human, } \\
\text { material and } \\
\text { time) }\end{array}$} & 10 & $\begin{array}{l}\text { A organização disponibiliza recursos financeiros e infraestrutura } \\
\text { física para as iniciativas orientadas ao conhecimento. }\end{array}$ \\
\hline & 11 & $\begin{array}{l}\text { A organização disponibiliza pessoas para realizar (executar) as } \\
\text { iniciativas orientadas ao conhecimento. }\end{array}$ \\
\hline & 12 & $\begin{array}{l}\text { A organização disponibiliza tempo para que as pessoas atuem nas } \\
\text { iniciativas orientadas ao conhecimento. }\end{array}$ \\
\hline \multirow{3}{*}{$\begin{array}{l}\text { Processes } \\
\text { andactivities }\end{array}$} & 13 & $\begin{array}{l}\text { A organização possui processos institucionalizados } \\
\text { (compartilhamento, criação, recuperação, outros) orientados ao } \\
\text { conhecimento. }\end{array}$ \\
\hline & 14 & $\begin{array}{l}\text { Os processos orientados ao conhecimento (compartilhamento, } \\
\text { criação, recuperação, outros) estão integrados ao fluxo de trabalho } \\
\text { das pessoas. }\end{array}$ \\
\hline & 15 & $\begin{array}{l}\text { Os processos orientados ao conhecimento (compartilhamento, } \\
\text { criação, recuperação, outros) são propostos segundo as } \\
\text { particularidades da(s) iniciativa(s) de conhecimento. }\end{array}$ \\
\hline \multirow{3}{*}{$\begin{array}{l}\text { Humanresourc } \\
\text { es } \\
\text { management }\end{array}$} & 16 & $\begin{array}{l}\text { As lacunas de conhecimento da organização são consideradas na } \\
\text { contratação de pessoas. }\end{array}$ \\
\hline & 17 & $\begin{array}{l}\text { A organização dispõe de meios para a capacitação } \\
\text { (desenvolvimento) das habilidades e competências das pessoas. }\end{array}$ \\
\hline & 18 & A organização dispõe de planos de carreiras para os funcionários. \\
\hline \multirow{3}{*}{$\begin{array}{l}\text { Training } \\
\text { andeducation }\end{array}$} & 19 & $\begin{array}{l}\text { A organização promove treinamento(s) para homogeneizar } \\
\text { conceitos e vocabulário da Gestão do Conhecimento. }\end{array}$ \\
\hline & 20 & $\begin{array}{l}\text { A organização promove treinamento(s) para as pessoas que } \\
\text { conduzirão (gestão) a Gestão do Conhecimento. }\end{array}$ \\
\hline & 21 & $\begin{array}{l}\text { A organização promove treinamento(s) para as pessoas que } \\
\text { realizarão (executarão) a(s) iniciativa(s) orientada(s) ao } \\
\text { conhecimento. }\end{array}$ \\
\hline Motivation & 22 & $\begin{array}{l}\text { A organização dispõe e faz uso de métodos para avaliação dos } \\
\text { funcionários. }\end{array}$ \\
\hline
\end{tabular}




\begin{tabular}{|c|c|c|}
\hline \multirow{4}{*}{$\begin{array}{l}\text { Dimension } \\
\text { (critical } \\
\text { factor) }\end{array}$} & \multicolumn{2}{|c|}{ Statement } \\
\hline & Item & Description \\
\hline & 23 & $\begin{array}{l}\text { A organização implementa sistemas de recompensas (financeiras), } \\
\text { gratificações (benefícios não financeiros) ou reconhecimento dos } \\
\text { funcionários. }\end{array}$ \\
\hline & 24 & $\begin{array}{l}\text { A organização promove meios para valorizar o comportamento } \\
\text { colaborativo, o trabalho em equipe e, ou, os processos orientados } \\
\text { ao conhecimento (compartilhamento, criação, outros). }\end{array}$ \\
\hline \multirow{3}{*}{ Teamwork } & 25 & A organização incentiva o trabalho em equipe. \\
\hline & 26 & $\begin{array}{l}\text { A organização considera a criação de equipes para atendimento das } \\
\text { iniciativas orientadas ao conhecimento. }\end{array}$ \\
\hline & 27 & $\begin{array}{l}\text { O objetivo e propósito da(s) equipe(s) criada(s) é apresentado aos } \\
\text { seus integrantes. }\end{array}$ \\
\hline \multirow{3}{*}{ Culture } & 28 & $\begin{array}{l}\text { A organização é tolerante a erros e reconhece o potencial de } \\
\text { aprendizado por meio desses. }\end{array}$ \\
\hline & 29 & $\begin{array}{l}\text { A organização busca estabelecer uma cultura que visa o } \\
\text { compartilhamento de conhecimento. }\end{array}$ \\
\hline & 30 & $\begin{array}{l}\text { Mediante a iniciativa orientada ao conhecimento a organiz ação } \\
\text { realiza um diagnóstico de sua cultura organizacional. }\end{array}$ \\
\hline \multirow{3}{*}{$\begin{array}{l}\text { Informationtec } \\
\text { hnology }\end{array}$} & 31 & $\begin{array}{l}\text { A organização pondera sobre a(s) tecnologia(s) adequada(s) à } \\
\text { iniciativa orientada ao conhecimento. }\end{array}$ \\
\hline & 32 & $\begin{array}{l}\text { A organização dispõe de meios tecnológicos (e-mail, chats, outros) } \\
\text { para estabelecer a conexão entre as pessoas. }\end{array}$ \\
\hline & 33 & $\begin{array}{l}\text { A organização busca consentimento da alta administração quanto } \\
\text { a(s) tecnologia(s) a serem adquiridas ou customizadas para } \\
\text { atendimento da iniciativa orientada ao conhecimento. }\end{array}$ \\
\hline \multirow{3}{*}{ Measurement } & 34 & $\begin{array}{l}\text { A organização possui indicadores e métricas, financeiros e, ou, não } \\
\text { financeiros, para medição das iniciativas orientadas ao } \\
\text { conhecimento. }\end{array}$ \\
\hline & 35 & $\begin{array}{l}\text { A organização realiza diagnósticos da Gestão do Conhecimento, } \\
\text { visando identificar lacunas a serem sanadas. }\end{array}$ \\
\hline & 36 & $\begin{array}{l}\text { A organização divulga aos funcionários os resultados das iniciativas } \\
\text { e diagnósticos de Gestão do Conhecimento. }\end{array}$ \\
\hline \multirow{3}{*}{ Pilot Project } & 37 & $\begin{array}{l}\text { A organização realiza, primeiramente, a implantação da(s) } \\
\text { iniciativa(s) de conhecimento em menor escala para posterior } \\
\text { implantação em maior amplitude organizacional. }\end{array}$ \\
\hline & 38 & $\begin{array}{l}\text { A organização avalia os resultados obtidos pela implantação da } \\
\text { iniciativa de conhecimento em menor escala organizacional (piloto) } \\
\text { para posterior implantação em maior amplitude. }\end{array}$ \\
\hline & 39 & $\begin{array}{l}\text { As lições aprendidas, obtidas por meio da(s) iniciativa(s) orientadas } \\
\text { ao conhecimento, são registradas. }\end{array}$ \\
\hline
\end{tabular}

Source: Research data, Belo Horizonte (2020), from the application of Content Validity.

The research instrument presented (Table 4) is the final version obtained through the Content Validation with the four expert judges. Thus, considering $\mathrm{CVC}_{\mathrm{c}}$ and $\mathrm{CVC}_{t}$ scores above 0.70 , this assessment instrument expresses quality suitable to be applied in the practice of holistic KM assessment.

\section{Conclusion}


The construction of research instruments demands an articulated process of reflection on the foundations that will support the statements, as well as their disposition in dimensions related to their semantics. However, even in the face of this intellectual effort, it is possible that the statements do not express clarity for their understanding, as well as do not promulgate coherence through the dimension in which it is attached and pertinence regarding its theoretical foundations. This is due to the construction process being imbricated with subjectivity, arising from the theoretical background of the instrument builder. Thus, it is necessary to validate the research instrument through credible scientific methods for this purpose.

In this research, an instrument for the diagnostic evaluation of holistic KM was constructed and validated through the scientific method of Content Validation, which was considered by four experts in this field. The motivation for this development is due to the limitation of existing diagnoses, which did not show the validation of the instrument, as well as because they neglected major factors to approach KM in an integral way. This report is not intended to grant demerit to existing instruments but rather to highlight the need to apply greater scientific rigor in their construction.

Thus, we believe that this study contributes by showing a form of validation and devising a research instrument concerning the management of coeval knowledge, which can be applied in an organizational locus, given that it expresses quality from the perspective of content validation. However, the validation process presented here received examination from four judges in the area, suggesting an opportunity for future research to promote the same validation with a more significant number of specialists.

In the meantime, we seek to combine the theory of KM, exposed here, with the practice of applying this diagnostic tool in organizations, which is also an opportunity for future research.

\section{References}

BALCEIRO, R. B.; ANTÔNIO, J. A. C. Implantação da gestão do conhecimento: um estudo de caso em uma empresa de energia. In:

RODRIGUEZ, M. V. R. y (org). Gestão do conhecimento e inovação nas empresas. Rio de Janeiro: Qualitymark Editora, 2010, p. 69-94.

BATISTA, F. F. Modelo de gestão do conhecimento para a administração pública brasileira: como implementar a gestão do conhecimento para produzir resultados em benefício do cidadão. Brasília: Instituto de Pesquisa Econômica Aplicada - IPEA. 2012. Disponível em: 
<http://repositorio.ipea.gov.br/handle/11058/754>. Acesso em: 31 jul. 2017.

BEIRÃO, E. S. et al. A. Resenha do livro o paradigma emergente e a prática pedagógica. Revista de Administração FACES Journal, v.11, n.1, p.323-327, 2020.

BEM, R. M.; COELHO, C. C. S. R.; DANDOLINI, G. Knowledge management framework to the university libraries. Library Management, v.37, n.4/5, p.221-236, 2016. DOI http://doi.org/10.1108/LM-01-2016$\underline{0005}$

BUKOWITZ, W. R.; WILLIAMS, R. L. Manual de gestão do conhecimento: ferramentas e técnicas que criam valor para a empresa. São Paulo: Bookman, 2002.

CAJUEIRO, J. L. G. Modelo de gestão do conhecimento para instituições de ensino superior. 2008. Tese (Doutorado em Engenharia de Produção) -. Universidade Federal de Pernambuco, Recife, 2015.

CASTILLO, L. A. M. ; CAZARINI, E. W. Integrated model for implementation and development of knowledge management. Knowledge Management Research \& Practice, v.12, n.2, p.145-160, 2014. DOI http://doi.org/10.1057/kmrp.2012.49

CORRÊA, F. A Gestão do Conhecimento holística e a aderência do modelo Fivaz e Pretorius. Transinformação, v.32, p.3-9, 2020.

CORRÊA, F.; RIBEIRO, J. S. A. N.; PINHEIRO, M. M. K. Aspectos da Economia da Informação: Arquétipo Conceitual Econômico e Social. Informação \& Informação (Online), v.22, p.185-214, 2017.

DAVENPORT, T. H; PRUSAK, L. Conhecimento empresarial: como as organizações gerenciam o seu capital intelectual. 11. ed. Rio de Janeiro: Campus, 1998.

FARÍAS, E. B.; MERCADO, M. T. C.; GONZÁLEZ, M. J. G. Modelo de gestión de conocimiento para eldesarrollo de posgrado: estudio de caso. Revista Electrónica de Investigación Educativa, v.18, n.1, p.128-139, 2016.

FILGUEIRAS, A. et al. Tradução e adaptação semântica do Questionário de Controle Atencional para o Contexto Brasileiro. Estudos de Psicologia, v.32, n.2, p.173-185, 2015.

FIVAZ, A.; PRETORIUS, M. W. A knowledge management framework for manufacturing firms in South Africa. In: Engineering, Technology and 
Innovation/International Technology Management Conference, Belfast. Anais eletrônicos... Belfast: 2015. DOI

http://doi.org/10.1109/ICE.2015.7438640

FUTAMI, A. H. Um Modelo de Gestão do conhecimento para a melhoria de qualidade do produto. 2001. Dissertação (Mestrado em Engenharia de Produçäo) - Universidade Federal de Santa Catarina, Florianópolis, 2001. HANASHIRO, A. Proposta de modelo de gestão do conhecimento no piso de fábrica: estudo de caso de Kaizen em empresa do setor automotivo. 2005. Dissertação (Mestrado em Engenharia Mecânica) -. Universidade Federal do Paraná, Curitiba, 2005.

HERNÁNDEZ-NIETO, R. A. Contributions to statistical analysis. Mérida: Universidade de Los Andes, 2002.

MACEDO, C. C. et al. Estratégia de integração das práticas de gestão do conhecimento ao modelo de gestão do SERPRO. In: SANTOS, A. R. et al. (orgs.). Gestão do conhecimento: uma experiência para o sucesso empresarial. Curitiba: Champagnat, 2001, p.49-79.

MEINICKE, D. SANTOS, A. M. Formação continuada numa perspectiva da educação para a inteireza: uma necessidade do professor de creche. Revista Interritórios, v.5, n.9, 2019.

MIRANDA, A. V. S.; ARRUDA, M. P.; MELO, S. M. M. Paradigma do cuidado complexo em saúde: produção de conhecimento no campo da enfermagem. Interfaces Científicas-Educação, v.8, n.3, p.27-40, 2020.

MOSCOSO-ZEA, O. et al. Knowledge management framework using enterprise architecture and business intelligence. In: International Conference on Enterprise Information Systems (ICEIS), 18, 2016, Roma. Anais eletrônicos.... Roma: 2016. Disponível em:

<https://scitepress.org/papers/2016/59160/59160.pdf>. Acesso em: 17 jun. 2020.

PEREIRA, H. J.; SKROBOT, L. C.; DANIELSSON, M. Gestão do conhecimento: um modelo corporativo integrado com foco na competitividade e sustentabilidade organizacional. In: RODRIGUEZ, M. V. R. y (org). Gestão do conhecimento e inovação nas empresas. Rio de Janeiro: Qualitymark, 2010, p.213-233.

PIRAQUIVE, F. N. D.; GARCÍA, V. H. M.; CRESPO, R. Knowledge management model for project management. In: International Conference on Knowledge Management in Organizations, 10., 2015, Maibor. Anais eletrônicos... Maribor: 2015. DOI http://doi.org/10.1007/978-3-319$\underline{21009-4 \quad 18}$ 
PROBST, G. ; RAUB, S., ROMHARDT, K. Gestão do conhecimento: os elementos construtivos do sucesso. Porto Alegre: Bookman, 2002.

RICHTER, F. A. Cultura organizacional e gestão do conhecimento. In: ANGELONI, M. T. (org.). Organizações do conhecimento: infra-estrutura, pessoas e tecnologia. São Paulo: Saraiva, 2002, p.29-43.

SALZANO, K. et al. A Knowledge management framework and approach for clinical development. Therapeutic Innovation \& Regulatory Science, v.50, n.5, p.536-545, 2016. DOI

http://doi.org/10.1177/2168479016664773

SÁNCHEZ, I. R. A.; PONJUÁN DANTE, G. Diseño de un modelo de gestión de conocimiento para entornos virtuales de aprendizaje en salud. Revista Cubana de Información en Ciencias de la Salud, v.27, n.2, p.138-153, 2016.

SANTOS, V. C. B.; DAMIAN, I. P. M. ; VALENTIM, M. L. P. A Cultura organizacional como fator crítico de sucesso à implantação da Gestão do Conhecimento em organizações. Informação \& Sociedade, v.29, n.1, p. 51-66, 2019.

SILVEIRA, M. A. S. G. et al. Gestão de processo de compartilhamento do conhecimento tecnológico em uma empresa do setor elétrico (CEMIG). Informação \& Informação, v.23, n.2, p.538-565, 2018.

TEIXEIRA FILHO, J. Gerenciando conhecimento. 2. ed. Rio de Janeiro: SENAC, 2000.

TERRA, J. C. C. Gestão do conhecimento: o grande desafio empresarial. 5ed. Rio de Janeiro: Elsevier, 2005.

ZANCHETA, F. H B; DAMIAN, I P M. Fatores críticos de sucesso na gestão do conhecimento: uma revisão bibliográfica. Biblos, v.33, n.1, p.23-45, 2019. 